\title{
Litchi (Litchi chinensis Sonn) propagation. New Technologies and innovations
}

\author{
Víctor Galán Saúco ${ }^{1}$, Michel Jahiel², Pedro Hernandez Delgado Modesto ${ }^{3}$, \\ Xu Ming Huang ${ }^{4}$, Sisir Mitra ${ }^{5}$, Oswaldo Kiyoshi Yamanishi ${ }^{6}$, Renata Aparecida de Andrade ${ }^{7}$
}

Abstract-The different propagation systems for litchis are reviewed. After examining the main morphological and developmental characteristics of the plant and the description of the structures and materials, including types of substrate required for the propagation of this species, the different methods for its propagation are discussed. Propagation by seeds is only used for breeding or research purposes or for raising rootstock for grafting. Although propagation by cuttings is done in many countries and stooling has been reported as highly successful in India, air layering is the most common commercial way of propagation for this species. Despite that the cambium activity varies from place to place around the stem with only $30 \%$ of the cambium being active at any one time grafting is of current use in China.

Index terms: Air layering, Litchi chinensis Sonn, propagation.

\section{Propagação de Lichia (Litchi chinensis Sonn). Novas tecnologias e inovações}

Corresponding author: vgalan@gmail.com
Resumo- Foram estudados os diferentes tipos de propagação da lichieira. Depois de examinar as principais características morfológicas e de desenvolvimento da planta e de uma descrição das estruturas de propagação, materiais e tipos de substrato necessários para esta espécie, descrevemse os diferentes métodos de propagação desta frutifera. A propagação por semente usa-se apenas para melhoramento, pesquisa ou obtenção de porta-enxertos. Embora a propagação por estaquia seja usada em vários países e que a propagação seja por mergulhia é praticada na Índia com grande sucesso, a alporquia é o sistema de propagação comercial mais usado no mundo para esta espécie. Ainda que a atividade do meristema varie em torno do caule, e apenas $30 \%$ do mesmo esteja ativo, a enxertia é prática comum na China.

Termos para indexação: Alporquia, Litchi chinensis Sonn, propagação.

Received: September 22, 2017.

Accepted :June 05, 2018.

Copyright: All the contents of this journal, except where otherwise noted, is licensed under a Creative Commons Attribution License. 


\section{Introduction}

The most commonly used commercial method of propagation of litchi is air layering. Litchis can also be propagated by seeds, grafting or cuttings. The highly heterozygotic characteristic of this species prevents the commercial propagation by seeds. Furthermore, litchi seeds have a very short viability and start losing their germinate capacity in less than 5 days, and, even under high humidity conditions, lost it completely in as maximum of 14 days, except if kept inside the fruit which preserve its viability for at least 3-4 weeks (Galán Saúco and Menini, 1989). They are also very slow to bear, usually 10 years or more (Menzel, 1985) and because of this are not appropriate for commercial plantings and are only used as rootstocks for grafting and for research and breeding purposes.

\section{development}

Morphological characteristics and plant

The litchi is a subtropical tree rarely exceeding 10-12 m height with a variable habit of growth from an erect to a weeping-willow appearance depending of the cultivars, propagation methods and pruning. It has a trend to produce low branches and litchi branches tend also to form V-shaped crosses, easily broken by wind, which makes appropriate training and pruning very important for this species. Its root system depend much of the method of propagation. Those grown from seeds either for direct planting or as rootstocks for further grafting possess a strong tap-root with a well-distributed secondary and tertiary root system. Those propagated by layering develop very shallow root system almost without tap root and with the feeding roots starting at soil level and extending over the first meter of soil depth (Galán Saúco and Menini, 1989). This evergreen tree produces a variable number of annual shoots starting in summer shortly after harvesting and continues till the spring flowering unless any climatic or other type of stress or chemical treatment (i.e. ethrel) stop flushing. Vegetative shoots may also be produced in spring or early summer on those branches which have not flowered. The small litchi flowers are grouped in panicles, usually terminal panicles produced on current season wood. There exist three types of flowers (I; II and III) which open generally in the order I-II-III and that vary in the degree of sexual development, but only the female type II will set fruits.

It is a common feature of some litchi cultivars to produce fruits with aborted seeds, the so called 'chickentongue seeds', in which the aril of the fruit usually occupies the space left by the seed and because of this they are very appreciated because of the higher percentage of edible pulp.
A peculiar characteristic of litchi which is of great importance for its propagation is the fact that Venning (1949) found that the entire cambium is active only during the earliest phase of secondary growth. Later on, cambium activity varies from place to place around the stem and only $30 \%$ of the cambium is active at any one time. Abutiate and Nakasone (1972) showed that the rate of cambial growth of the stock was an important factor in the degree of success in grafting lychee in Hawaii. Due to the limited and unpredictable activity of the cambium, which is related to the onset of leaf flushing, and since the external stem surface offers no clue as to which portion of the cambium is active, it is purely by chance that two active areas can be brought together. This explain, as will be seen late on this paper, the importance of providing an environment after grafting that keeps the scion alive for a time-period long enough until resumption of cambial activity happen again in the area of contact between stock and scion and may explain the beneficial effect of a wrap of plastic film covering the grafting (Nelson, 1954).

\section{Propagation structures}

\section{Types of structures}

The production structures of young plants or nurseries must meet specific technical criteria that ensure the production of healthy plants that have all the qualities granting a good transplanting to the field.

\section{Characteristic features of the implantation site}

The optimal implantation conditions are as follow:

- Located near a clean water supply point that is available all year long.

- Have a flat surface with no stagnant water zone and no risk of inundation in case of heavy rains.

- Located near an access track for evacuating the products.

- Have a defined surface that is well adapted to the number of plants to be produced annually.

- Isolated from commercial litchi plantings to avoid risks of pests and diseases incidence.

- The construction and management works will focus mainly on:

- The protection of the plants from adverse climatic conditions, like excess sunshine, cold temperature, flooding or winds and also from pests and diseases.

- The discharging of surface waters.

- The security of the site against thefts and animals.

- The existence of appropriate instillations for propagation works.

- The availability of a mother block field.

- Mother block fields must accomplish with the following characteristics; 
- Cultivars should be clearly identified and with total varietal guaranty.

- Should be easily accessed and should be kept free of pests and diseases.

- Cultural techniques applied should be conducted at the best.

- If patented cultivars are included in the field those should be kept in a different section that the normal free cultivars and adequately protected.

- Under tropical conditions the armature of the shading system can be made with local materials (cut wood, straight branches, bamboo, etc.) or with imported materials (galvanized or iron tubes, or others). In order to ensure optimal shading and create an atmosphere that will favor the development of the young plants, the following criteria will be respected:

- Shade the whole zone that is devoted to the plant production.

- Position the shading net or the system chosen for this purpose at a height between 250 and $300 \mathrm{~mm}$.

- Use shading nets or tarpaulin that can filter 50 to 60 $\%$ of sunshine.

Under subtropical conditions and also in windy locations it is advisable the construction of propagation greenhouses with an structure made with wood, galvanized or iron tubes covered with net, polycarbonate plates, or even glasshouses, depending on the climatic and economic conditions of each location. This will also serve as protection against pests and diseases. Greenhouses should be well isolated with double door of entrance and should have the possibility of a good ventilation and even cooling system as well as provided with nebulizing installations to increase humidity and protect from high temperatures during hot weather. It is also desirable that greenhouses have an adequate ventilation system and that be provided with cooling system and nebulization systems to avoid extremes of high temperature and low humidity.

In areas with high pluviometry, the elimination of surface waters and of rainwater stagnation points is essential for limiting the spread of diseases that might harm the development of young plants. Small drainage channels will be created and if possible the space will be re-arranged by covering the soil with a gravel layer or a permeable substrate.

Domestic and wild animals must be prevented from walking on the site in order to eliminate any risk of plant deterioration by trampling, leaves consumption or animal dejections, etc.

The propagation site must have on its proximity an independent place for storage of propagation substrata and preparation of mixtures close to the propagation general structure. Propagation tables made with material to oxidation and corrosion should be of adequate dimensions for manipulation of the plants with about $80-90 \mathrm{~cm}$ height and $100 \mathrm{~cm}$ width which will allow to place about 5-6 transversal lines of potted plants per table easily accessible. If the potted plants are to be placed on the soil surface instead of on tables the containers should be isolated from it with anti-rooting nets to avoid rooting on the soils surface unless the nursery soil will be made with concrete or similar materials. In dry regions when no nebulizing systems have been installed it should be advisable to have humid tunnels or at least to cover the plants with plastic bags to avoid desiccation of plants during dry periods. It is also desirable that a separate place for substrata disinfection will be available close to the propagation site.

\section{Plant production at the nursery}

The litchi plants must be planted in an appropriate bag, as it may remain in this container for many months before its transplantation onto the orchard. The type of nursery bag that is recommended nowadays (provided that the trees do not stay in the nursery longer than a year) is as follow: black color, $80 \mu$ thick at least, 175 x $150 \times 350 \mathrm{~mm}$ sized, perforated on its length. If the tree must remain in the bag for a long period, the size of containers must be bigger: 175 x 150 x $400 \mathrm{~mm}$. Smaller bags must not be used in that case as the roots will not have enough room for developing and may go out of the bag through the draining holes. Plastic bags of around 15 $\mathrm{cm}$ of diameter and more than $30 \mathrm{~cm}$ height can also be used. It is convenient that both, pots and plastic bags, be preferably open at the bottom and placed on an structure which avoids direct contact with the soil to permit air pruning and avoid root deformation. If this is not possible, put them on a surface that is concreted, covered with gravel or with a film specially made to avoid the penetration of the roots into the soil. That precaution allows avoiding the development of root diseases (like nematodes).

Make sure that water draining is done properly. If the water stagnates at the top of the bag it is recommended to increase the number of holes. A source of clean water must be used for watering the plants. As many diseases and the nematodes are spread by irrigation water, the water used must be treated with chemical products or come from a clean source (a drill for instance).

Before the plants are sold or transplanted onto an orchard, they must first be hardened through sunshine exposure for 3 weeks.

The composition of the substrate used for filling in the nursery bags plays an important role in the plants rooting and their growth. The mixture that is obtained must ensure a good draining of the irrigation water, a good growth of the roots and so on. Too clayey a substrate (too heavy) will tend to fill the holes for discharging water. Too light a substrate (sandy) will not structure the clod of the plant properly and will be subject to frequent water deficits due to quick water draining. A 
good mixture will consist of $1 / 3$ of river sand or other inert material like lapilli, vermiculite, $1 / 3$ of alluvial soil and $1 / 3$ of well decomposed organic matters (if possible from plant wastes and not animal wastes) or peat moss. The mixture must have a pH between 6 and 7. According to the quality of the substrate, it is possible to add a little phosphate fertilizer and to rectify the $\mathrm{pH}$ (increase) by adding some agricultural lime. If pine barks are included in the substrate, it is advised to check the mixture $\mathrm{pH}$ regularly, as it may decrease. The substrate used for the plants must be first treated by steaming, heating the substrate at $80^{\circ} \mathrm{C}$ temperature for 30 minutes in order to eliminate the nematodes, fungi and weeds seeds. advised to. The incorporation of soil from old plantations has been recommended because of the potential benefit of soil mycorrhizae present (Higgins, 1917; Kadman and Slor, 1974) but soil must be free from pests and diseases and the required disinfection will kill the arbuscular mycorrhiza fungi. Before treating the substrate, it is advised to humidify it in order to germinate the weeds seeds, which will allow destroy them more easily during the treatment.

Labeling of plants is not compulsory. Yet, if different varieties are produced, it is advised to label each plant in order to distinguish it from the others. However, the labels must be removed after the plant has been transplanted in order to avoid the girdling of the tree trunk.

In terms of sanitary prevention the nursery man must watch the quality of the equipment used for maintenance works (the shears must be well sharpened and regularly washed with water and chlorine, for instance). Plants must be free from any insect traces (mainly bark drillers) and from diseases. Special attention will be given to the nursery organization in terms of plants classification according to their age, variety and development (weak or distorted plants must be eliminated).

The nursery must be provided with adequate installations for irrigation and fertilization the more automatically regulated as possible according to technical and hand labour availability and cost. Irrigation facilities should allow frequent water application to the pots which permit to keep substrata humidity at the right level avoiding flooding of it. It may be ideal to have direct localized irrigation at each pot with microtubes, simple or multidrip diffusors as well as sprinkling or mini sprinkling irrigation systems.

Good water quality is essential for litchi nurseries with the following considerations depending in electric conductivity (EC) values $\left(\mathrm{dS} / \mathrm{m}\right.$ at $\left.25^{\circ} \mathrm{C}\right)$ : Excellent (EC $<0.25$ ); Good (EC between 0.25-0.75); valid (EC between 0.75-2.0); doubtful use (EC 2.0-3.0) and inadequate (CE >3.0). In the case of alkaline water the $\mathrm{pH}$ should be corrected wit nitric, sulphuric or phosphoric acid.

Chemical fertilization can be applied straight to the pot but chemical fertilizers should be placed at an appropriate separation from the plant stems. Although it is advisable to establish the fertilization in the nursery according with a chemical analysis of the substrate, slow release fertilizers at the dosage of 2-3 $g$ of NPK 14-7-14 or similar can be recommended. The same NPK fertilization can be used in the case of fertigation but always taking care of not increasing much the electrical conductivity. The incorporation of microelements is in general also appropriate for litchi propagation to avoid carential situations.

The presence or incorporation of organic matter to the substrata and the use of mycorrhiza is good for litchi propagation favouring root development as well as growth of the aerial part of the plant, but if mycorrhiza is used phosphoric fertilizers should not be applied to the propagation media.

A good nursery plant has a straight stem with branches (future framework branches) that branch horizontally at about $400 \mathrm{~mm}$ high. No branching under $400 \mathrm{~mm}$ stem must develop.

\section{Propagation methods}

\section{Propagation by seeds}

Litchi seed viability is extremely short. If exposed to the air in the shade under ambient humidity conditions they begin to shrivel in less than 24 hours and in five days are no longer capable of germinating. They may, however, be preserved for up to 8 weeks between two $2.5 \mathrm{~cm}$ thick layers of spaghnum moss (Higgins, 1917), or for a shorter period wrapped in peat in a refrigerator (Cull and Paxton, 1983), or for at least a month in the shade in closed Petri dishes dusted with an appropriate fungicide (Galán Saúco and Menini, 1989). Menzel (1985) reported that seeds can also be stored for up to 56 days at $8^{\circ} \mathrm{C}$ which roughly agreed with $\mathrm{Fu}$ et al., (1990) which indicated that seeds are viable for up to 60 days when stored at $5^{\circ} \mathrm{C}$, although McClelland (1944) found temperatures of $3^{\circ} \mathrm{C}$ detrimental for litchi seeds.

After being separated from the fruit and removing the whole flesh, the seeds must be sown horizontally to a depth of $1-2.5 \mathrm{~cm}$ in in trays in .a well-drained substrate (see above paragraph 'Plant production at the nursery for the composition of the substrate). The incorporation of soil from old plantations to the substrate has been recommended because of the potential benefit of soil mycorrhizae present (Higgins, 1917; Kadman and Slor, 1974) but soil must be free from pests and diseases and the required disinfection will kill the arbuscular mycorrhiza fungi. Germination should normally commence within 3 days. When the young plants had reached a height of 10$15 \mathrm{~cm}$ they should be transplanted into individual bags. To facilitate transplanting, they should be at a distance of not less than double their length sown (around 8-10 cm) 


\section{Propagation by air lavering}

This is the most widely used propagation method for litchi and the one which gives the most successful results. The major advantages are that it is simple to use and genetically identical plants to the mother plant are produced. The main disadvantages derives from the damage caused to the parent plant if a large number of layers is required and from the fact that the cultivar required to propagate may not be well adapted to adverse water, soil or climatic conditions, lacking the possibilities of adaptation through the use of a rootstock like in the case of grafting. The procedure for air layering has been described by a number of authors (Yee, 1971; Kadman and Slor, 1974; Ireta Ojeda,1975; Bolt, 1983; Menzel, 1985; Galán Saúco and Menini, 1989; Mitra and Ray, 2005 et passim) but will be summarized below.

Criteria for selection of mother plants for air layering

Selected mother plants for air layering should be young (preferably below 15 years of age), vigorous and healthy. Mother plants should be nourished with recommended doses of nutrition to encourage more vigorous shoots. It should be free from any pest and disease infection for which regular integrated pest and disease management should be practiced. The mother plant blocks in the nursery should be in the sunniest situation with necessary irrigation facilities.

\section{Criteria for selection of branch for air layering}

Air layers are made on healthy and mature $(\geq 1$ year old) upright shoots. The diameter of stem at girdling point should be $1-2 \mathrm{~cm}$ and its length above this point should be $40-60 \mathrm{~cm}$. Roots usually developed faster on branches with mature vegetative growth compared to recently flushed wood. Thin branches give rise to air layers with a poor root system and smaller trees which took longer to come to bearing. Stems older than two years $(>2.0 \mathrm{~cm}$ diameter) can be used in some cases, but rooting is less satisfactory and the larger plants produced are somewhat more difficult to handle after rooting. Shoots in full sun rooted better ( $90.0 \%$ compared to $36.7 \%$ ) than shoots in the shade (Ireta Ojeda, 1975). Likewise shoots lying on the north-east and north-west parts of the crown rooted better (Kanwer and Kahlon, 1986). Shoots from young mother plants usually rooted easily than older trees.

\section{Air layer operation}

Before air layer operation lychee tree must be well hydrated to facilitate the bark removal. The following steps are usually undertaken for air layer operation (Fig.2):

- select a mature rectilinear branch with 2.5 to 5.0 $\mathrm{cm}$ in diameter with more than $80 \mathrm{~cm}$ in length;
- remove the bark ( 2 to $3 \mathrm{~cm}$ wide) with a sharpened knife or adapted pliers (Fig. 1);

- cover the debarked ring with wet sphagnum moss enveloping with clear flexible plastic film or with pine bark or coconut fiber substrate;

- compress the ball formed to enhance rooting;

- small balls with sphagnum moss root faster (60 to 75 days) than in the pine bark and coconut fiber (medium to large balls) which needs two to three weeks more for removal from the mother plant.

After cutting the rooted branch from mother plant, the branch crown can be removed or maintained depending on the size of the nursery plant. On single branch system, the crown is removed 60 to $80 \mathrm{~cm}$ above the rooted ball and potted. With untouched crown, the leaves are removed and potted. Plastic bags (1.5 to 2.0 liters) filled with soil with good drainage or commercial substrate are commonly used. Wet the soil/substrate before transplanting. Lychee young roots in the air layer are very sensitive to chemical fertilizers and raw manure or compost; so, add if necessary with caution to avoid root burning.

Time required from potting to transplanting to the field depend also on type of nursery plant raised. For single branch, without the crown, it is recommended to keep it in the nursery until hardening of the second flush, which will need five to six month after potting. On the other hand, rooted branch with crown is much faster than the first one and is widely adopted by the nurseries because they can sell at the end of leaf hardening of the first flush that takes just 60 to 90 days after potting and reduce considerably the cost of production.

\section{Rooting media}

Sphagnum moss (Fig. 3) collected from sea banks is the best rooting media for lychee air layering but can be replaced by commercial substrate made by pine bark or coconut fiber. The inconvenience is the size of the rooting ball, which is two to three times bigger than the first one. On the other hand, it can be used for direct planting in the field.

The raw sphagnum moss should be washed with tap water to remove excess of salts and kept in basket filled with water for hydration before use and the excess of water removed just by hand compression. In case of pine bark or coconut fiber substrate, it is recommended to wet it (never saturate) before putting in the clear flexible plastic bag $(20 \times 10 \mathrm{~cm})$ and lock the top of the bag to facilitate transport and further fixing.

\section{Propagation by stooling}

Stooling, also known as mound layering, consists in cutting back the main stem of the plant to the ground in winter and covering the newly developed young stems with a mound of soil in spring. These juvenile stems produce adventitious roots in the soil and are removed in 
due course of time to set out as separate plants. Cinturing shoots and application of plant growth regulators before mounting promote root formation. Litchis are particularly suited to this method of propagation, since they have stiff branches, which do not bend easily and are capable to produce several shoots each year (Menzel, 1985). In this method the mother plant can be used year after year. Ram and Majumder (1981) in India recorded 84 per cent success with stooling as compared to 71 per cent with air layering. The survival percentage was also higher in case of stooling (82\%) compared to air layering (46\%). Root number, length and average thickness of root were all superior with stooling. Using of IBA at 2,500$5,000 \mathrm{ppm}$ in lanoline paste on the cinctured area before mounding of soil around the cinctured bases enhanced root formation. The method was reported as simpler, quicker and economical than the age-old air layering.

\section{Propagation by cuttings}

Litchi is not commercially propagated by cuttings, though the method is simple and inexpensive. The cuttings may be used as a rootstock to take the advantages of early grafting compared with seedling stock. Litchi is a difficultto-root woody perennial species, requiring elaborate facilities like misting, temperature and humidity control for higher success in rooting. Several factors like type of wood, the stage of growth used in taking the cuttings, time of the year when the cuttings are taken, genotypes etc. can influence the success of cuttings to root.

\section{Type of cuttings}

Hardwood cuttings from an active flush of new growth root more readily than those from dormant hardwood cuttings. Semi-hardwood and softwood cuttings are also rooted easily under favorable rooting environment and with auxins. Cuttings are usually $15-20 \mathrm{~cm}$ in length and $8-15 \mathrm{~mm}$ in diameter. Thicker diameter cuttings of the same age wood root less readily and have rather fragile root systems. Green woody cuttings root better than dark grey ones.

Shoots of 1.5 months old spring flush are highly suitable for preparing the cuttings. Between terminal and sub-terminal cuttings, the sub-terminal is better as they normally have higher survival percentage.

The cuttings should have at least three nodes lengthwise so that one can be in the rooting medium and the two can give rise to shoot growth. The basal cut should be at an angle, rather than perpendicular to the central axis of the stem. This makes it easier to cut, easier to stick into the media, and decreases the likelihood of damage to the xylem vessels in the stem. Further, making the cut immediately below a node results in a greater concentration of roots at the more basal parts of the cuttings.

\section{Time of taking cuttings}

In India, the cuttings are best taken in April after the spring growth flush or, in August- September when the monsoon is active with warm and humid climate. In Queensland Australia, semi-hardwood and hardwood cuttings, collected from cv. Bengal prior to flower initiation in May, showed 70-80 per cent rooting (Paxton et al., 1978). In Brazil, cuttings taken from terminal shoots of 21-year-old plants in July exhibited 72 per cent survival (Leonel et al., 1994).

\section{Treatments to induce rooting}

Several treatments (e.g. girdling, use of growth regulators, misting and bottom-heat in benches) are used to alter physiological, nutritional or environmental condition of the stock plant or portion of the plant for increased rooting of cuttings. Girdling or cinturing the stem before taking cuttings, block the downward translocation of carbohydrates, hormones, and other possible root promoting factors and can result in an increase in root initiation. Cinturing of shoot at 8 weeks before taking the cutting improved rooting of "Brewster" cuttings. Although there is substantial increase in carbohydrates in the shoots due to girdling, and fail to result in increased rooting of cuttings.

Treating the cuttings with plant growth regulators particularly auxins has been widely practiced to increase the percentage of cuttings that from roots, to hasten root initiation and to increase the number and quality of roots produced per cutting. Treatment with indole-3butyric acid (IBA) produces a fibrous root system both at lower and higher concentrations. Mitra and Bose (1991) achieved 85 per cent success in rooting of cuttings with the combination of ethrel $\left(2 \times 10^{-4} \mathrm{M}\right)$ and IBA $\left(2 \times 10^{-2} \mathrm{M}\right)$. Ethrel was sprayed twice on the stock plant at 10 days interval before taking the cuttings. Addition of phenolic acid viz. $p$-hydroxy benzoic acid, $p$-coumaric acid and ferulic acid at 0.2 per cent as preplanting treatment with IBA improved the quality of roots (number of roots/ cutting, length of roots). For application of IBA, several methods viz. prolonged soaking, quick dip, powder dipping and use of lanolin paste have been used with varying degree of success. The best response was obtained with IBA at $100-200 \mathrm{mg} \mathrm{l}^{-1}$ (prolonged soaking for $24 \mathrm{~h}$ ) or 3,000-10,000 $\mathrm{mg} \mathrm{l}^{-1}$ (quick dipping for 5 seconds).

\section{Planting of cuttings for rooting}

Cuttings are stuck fairly deep $(3-4 \mathrm{~cm})$ to reduce the danger of drying and to give support. They usually take 30-60 days or even more to strike root. This is indicative of a slow root development process in litchi. It is essential that during this period the rooting medium be kept moist as the root primordial are extremely succulent and should be favoured with an adequate supply of water in the early development. Some of the hazards in propagation 
from cuttings are drying out of the rooting medium and low atmospheric humidity. These are eliminated by using either a constant or an intermittent mist over the propagating bed. Intermittent mist greatly increased the percentage of cutting rooted and an early success. Likewise, maintaining a constant warm temperature at about $30 \pm 2^{\circ} \mathrm{C}$ at the base of the cuttings greatly stimulates rooting. This is best done by providing bottom heat from thermostatically controlled electric heating cables or hot water pipes under the rooting frames. Rooted cuttings should be transplanted in polybags filled with good fertile soil and compost. When the root system has become firmly established and the top has attained sufficient leafy growth, the plant is ready for setting in the field.

\section{Propagation by grafting}

Grafting is an asexual propagation method that involves uniting two parts, the rootstock and the scion, from different plants into one plant. The unit plant is allowed to grow, where the rootstock contributes to the root system while the scion to the canopy. As a result, the scion cultivar is multiplied. Grafting has long been used in China, and is still a major method for propagation of litchi.

\section{Reasons for use}

Grafting needs skills and experiences as well as sharp tools to ensure success. It also takes longer than air-layering or cutting as grafting needs to start with preparing seedlings of the rootstock, which takes around a year from seed sowing to when seedlings are ready to use. However, grafting has a number of advantages over other propagation methods:

First, it possesses all the advantages of vegetative propagation methods, such as maintenance of the wanted traits of the to-be-propagated varieties, and early bearing due to no juvenile phase is present as scions are taken from plants in adult phase. In Guangdong, China, grafted trees start to bear fruit in the third year from transplanting to the field.

Second, grafting has a higher propagation coefficient than air-layering or cutting. In grafting, bud sticks consisting of 1 to 3 buds are used. Therefore, a large number of scion pieces can be collected from one mature tree. In practice, collecting bud sticks can be done as a means to thin dense shoots and will not affect the productivity of the source trees. In case of air-layering, the branches to be girdled and later cut off as layers are mostly medium-size branches ( 2 to $3 \mathrm{~cm}$ in diameter), which are much fewer than smaller shoots for grafting budwood in a source tree. Moreover, production of air layers are at the expense of reduced productivity of source trees in the next seasons, because these branches are finally removed, reducing foliage area for fruit set. Although, the air-layered branches may set better due to girdling effect in current season, it is generally not recommended as fruit bearing inhibit root growth of the layers.

Third, through grafting, rootstocks may affect many traits of the scion cultivars, such as hardiness, tree vigor and flowering time. Although there is no systematic study about the effect of rootstock on hardiness in litchi, it is well recognized that rootstocks confer resistance to stresses, especially soil-born stresses (eg. drought, salinity and soil-borne diseases) to susceptible cultivars. Studies have shown that tree vigor of the same litchi cultivars can be tremendously influenced by rootstocks $(\mathrm{Hu}$ et al., 2010), and therefore canopy size can be controlled by using appropriate rootstocks. However, up to now no universal dwarfing rootstock has been found in litchi. Differential tree vigor caused by rootstocks is a result of difference in compatibility between the scion and different rootstocks. Based on our field observation, flowering time of scion cultivars can be advanced by grafting onto an early cultivar, which has less chilling requirement for flowering induction and thus earlier production of florigen that triggers flower differentiation.

Fourth, grafting as a method of propagation makes use of seedlings as rootstock. The seminal root develops into a tap root system with a dominant central axis that allows faster penetration to deeper soil compared with cuttings or air layers. Hence, grafted trees have a better anchoring root structure which contributes stronger resistance to wind damage.

\section{Criteria for selection of rootstocks}

Rootstocks contributes to the root system and exert strong effect on the vigor of the propagated litchi trees. The first criterion for selection of rootstocks is the compatibility of the rootstock with the target cultivars. Table 1 shows the grafting compatibility between rootstock (seedling) and scion cultivars. Cultivars like 'Huaizhi', 'Baila' and 'Baitangying' are compatible to most litchi cultivars and can serve as universal rootstocks for litchi propagation. However, cultivars like 'Heiye' ('Hak Yip'), 'Dazao' ('Taiso' or 'Mauritius'), 'Sanyuehong' and 'Shuangjianyuhebao' had a poor compatibility with some cultivars like 'Nuomici'. They are therefore not suitable for grafting with 'Nuomici' scions. Choosing the compatible rootstock is a precondition for grafting success and quick tree establishment.

When preparing seedlings for rootstock, only fully developed seeds should be chosen. Litchi may, depending on cultivars, bear shriveled or partially developed seeds that fail to germinate or germinate poorly and should be, of course discarded for use as rootstocks. Litchi seeds are recalcitrant and highly susceptible to desiccation. Once separated from the flesh tissue, the exposed seeds quickly lose vigor due to evaporation. Therefore, after taken from the fruit, they should be placed in wetted sand as soon as possible to force germination. Sprouted seeds are sowed in a prepared bed at a distance of $8-10 \mathrm{~cm} \times 10-12 \mathrm{~cm}$. 
When the stem diameter at ground height grows to around $6 \mathrm{~cm}$, they are ready for grafting.

Criteria for selection of aerial part (scion and plant)

Scion materials are taken as budwoods from source trees of the to-be-propagated cultivar. Generally hardwoods of current season or previous season are used. Criteria for selection of budwoods are based on several factors that may influence grafting success:

First, budwoods should be taken from trees at the stage around initiation of new flush. Litchi trees undergo recurrent flushing, with terminal buds alternating between rest and growth status even under constant growth conditions. The bud rest of litchi is a kind of developmental endodormancy that starts as new leaves expands. It is removed by unknown endogenous mechanisms when the new leaves become fully mature, and the buds are ready for a new cycle of flush growth. If we take budwoods with buds that are about to break, the bud growth of grafted scion will take place soon after grafting, while it will take much longer if we use budwoods with buds in endodormant status. Early budbreak of the scion will encourage early healing of the joint and reduce the chance of scion death due to desiccation.

Second, choose budwood from exposed canopy.The shaded shoots at lower or inner position of the canopy fail to grow as shading strongly suppress budbreak forcing the buds to maintain dormancy (Mo et al., 2013). Therefore, budbreak will be delayed if budwood is taken from the shaded shoots compared with that from the exposed shoots.

Third, the diameter of the budwood should be no larger than the stem diameter of the rootstock seedlings to be grafted upon.

Fourth, budwoods should be collected on the same day of grafting operation. Leaves on the budwoods should be all removed to minimize transpiration. If budwoods have to be collected earlier, they should be well protected from desiccation. They can be stored in wetted sands or wrapped in fresh leaves for a couple of days before grafting or wrapped with appropriate protective materials like parafilm that avoid desiccation.

\section{Time for grafting operation}

Grafting is operated in seasons with climate favorable for bud growth, with average temperature in daytime between 20 and $30^{\circ} \mathrm{C}$. In China, grafting is generally carried out in spring and autumn. Spring grafting is done from February to April, while autumn grafting is conducted from September to October. Unless in greenhouses, avoid grafting operation in times when heavy rain or abrupt temperature fluctuations may occur within 5 days after grafting.

\section{Methods of grafting}

Various methods of grafting are available. Coming to all of them is a good contact between the cambium tissues of the scion and rootstock.

'Whip grafting' involves joining of the scion and rootstock across their cut surface made at the same angle. Budwoods are cut into 3-4 cm sticks with 2-4 buds and a sharp and clean downward (basipetal) angled cut is made through the internodes on the budstick. A similar cut is made on the rootstock around $15-20 \mathrm{~cm}$ from the ground. The joining enables the budstick to maintain an upright position after grafting. However, whip grafting is useful when the stem diameters of the budwood and rootstock are similar so that perfect contact of their cambium tissue will be ensured. It also requires smooth cuts of the budwood and rootstock at the same angle, which need some skill. Due to these limitations, whip grafting is not commonly used in China.

'Cleft grafting', where a cleft cut is made across the center of the rootstock and then a base-sharpened budstick with 1-2 buds is inserted into the cut, is relatively easier to operate compared to whip grafting (Fig. 4). However, cutting through the center of the rootstock needs force, which is not welcome by operators.

'Bark grafting' is easier than the above two methods. It involves a vertical cut made on both the scion and rootstock, removing a strip of bark from the two parts at similar width and exposing the cambium tissue. The scion and rootstock are put together at the cut surface (Fig. 4). The scion used in this method can be a short budstick with only one bud. This method is most commonly used for propagating litchi as it needs much less skill and force to operate.

After grafting, the conjunction and the budstick must be well protected with soft polyethylene film or parafilm. The young plants should also be protected from sun-burning with shading net. Within one week after grafting, irrigation should be restricted because high soil availability will cause bleeding at the cut surface of the rootstock. Water oozed out will cause hypoxia at the conjunction between the scion and rootstock, which prevents healing process. If budbreak on the scion does not occur 30 days after grafting operation, the chance of success is slime and grafting needs to be redone.

\section{Criteria for releasing seedlings from nursery}

The seedlings ready for transplanting or sale should have the following characteristics:

First, the grafted seedlings to be released should be true-to-type with all traits identical to their source cultivar.

Second, the grafted seedlings should not be with an incompatible joint reflected by tissue swelling above the joint. 
Third, the young plants should be healthy with no diseases or pests. The plant height should be $50-60 \mathrm{~cm}$ of height with 2 to 3 branches and the trunk diameter at 2 $\mathrm{cm}$ above the joint larger than $0.5 \mathrm{~cm}$. To reach this size, the scion should have undergone at least two cycles of flush growth.

In case the propagation has been done directly on the soil, two weeks before uprooting, the immature flushes should be headed to encourage leaf maturation. Prior to uprooting, the seedlings should be well irrigated so that the soil and root will stick together during uprooting with minimum damage on the root system. The young plants should be uprooted with soil at a depth of $20-25 \mathrm{~cm}$ and a diameter of $12-15 \mathrm{~cm}$. The root/soil is wrapped with black plastic bag immediately after uprooting. To reduce desiccation due to transpiration, the seedlings should be pruned to a height around $50 \mathrm{~cm}$ removing most of the leaves leaving 3 to 4 compound leaves each with 2 small leaves. These operations are not necessary in the case that the grafting process has been done in seedlings prepared on bags at the nursery, since almost no disturbance of the root system will occur during field transplant.

In the case that seedlings for grafting were not planted directly on the soil the following recommendations must be made"

The germinating beds filled with the propagation substrate must have a depth of at least $25 \mathrm{~cm}$ and seeds should be placed at least $15 \mathrm{~cm}$ apart. The polyethylene nursery bags to which the seedlings should be transplanted after germination when they reach $10-15 \mathrm{~cm}$ to be later grafted must have at least a minimum of $175 \times 150 \times 400$ $\mathrm{mm}$ to avoid root deformation problems.

Table 1. Grafting compatibility between different litchi rootstock and scion cultivars.

Rootstock cultivar

\section{Compatibility of scion cultivars}

\begin{tabular}{|c|c|c|c|}
\hline & Good & Poor & Reference \\
\hline Huaizhi (Waichee) & Most cultivars & No found & \\
\hline Heiye (Hak Yip) & $\begin{array}{l}\text { Sanyuehong, Jizuili, } \\
\text { Xuehuaizhi, Guiwei }\end{array}$ & Nuomici, Baitangying, Qingzhouhongli & - \\
\hline Dazao (Taiso, Mauritius) & Feizixiao & $\begin{array}{l}\text { Nuomici, Baitiangying, Jizuili, } \\
\text { Qingzhouhongli, Xuehuaizhi }\end{array}$ & - \\
\hline Baila & Most cultivars & Not found & \\
\hline Baitangying & Most cultivars & Not found & $\mathrm{Li}, 2008$ \\
\hline Sanyuehong & Heiye, Feizixiao & Nuomici & \\
\hline Shuangjianyuhebao & $\begin{array}{l}\text { Maguili, Lingshanxiangli, } \\
\text { Feizixiao }\end{array}$ & $\begin{array}{l}\text { Nuomici, Guiwei, Qingzhouhongli, } \\
\text { Sanyuehong, Hongmili }\end{array}$ & Li et al., 2014 \\
\hline Bengal & $\begin{array}{l}\text { Heiye, Nuomci, Feizixiao, } \\
\text { Kuai May Pink }\end{array}$ & -- & Pires et al., 2014 \\
\hline
\end{tabular}

Indicates no report 


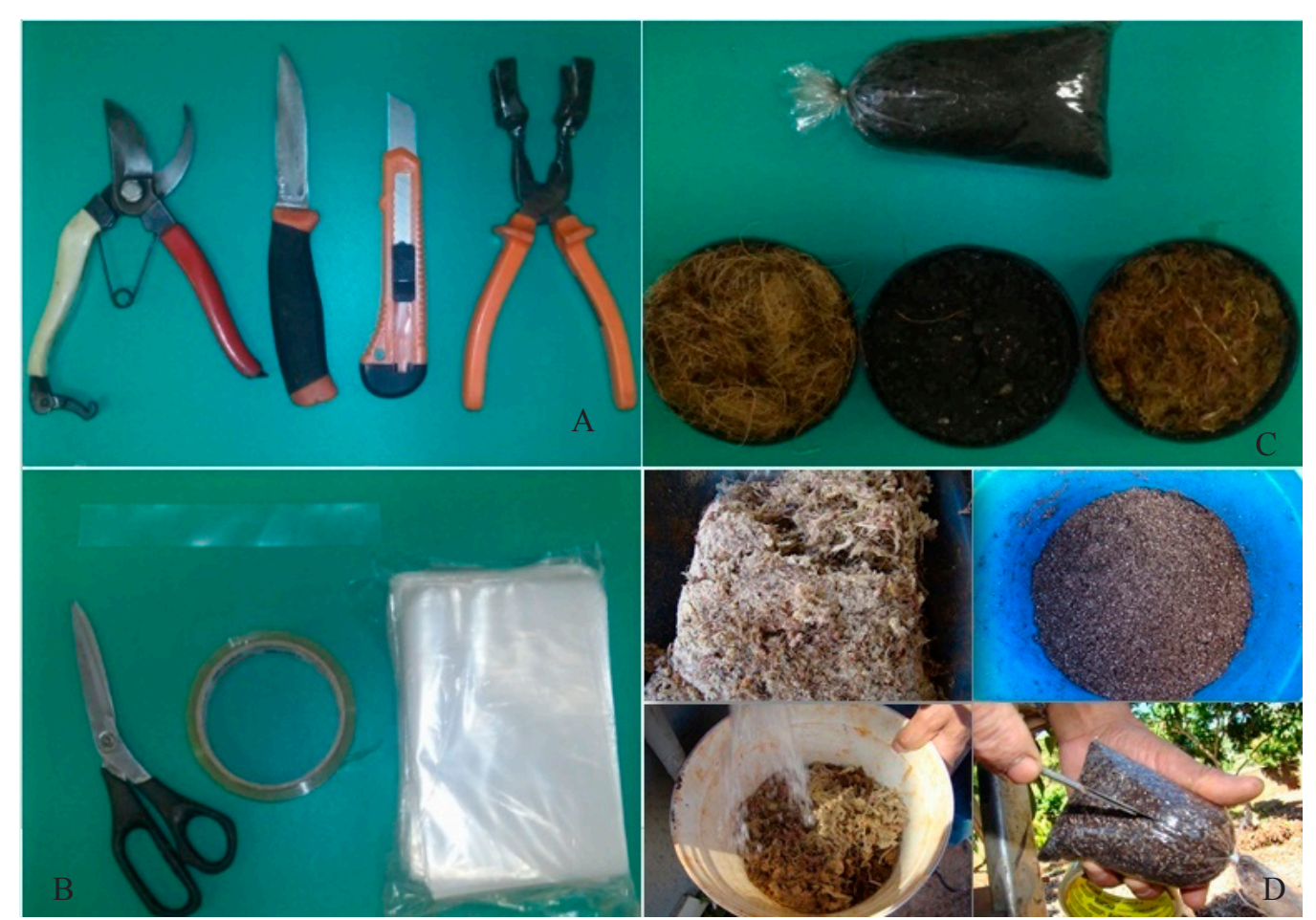

Figure 1. Materials used for the preparation of the air layer; A- Strip of bark (2 to $3 \mathrm{~cm}$ ) carefully removed with knife, tree must be well watered before air layer operation for bark loosening; B-C - Debarked ring covered with well-compressed wet sphagnum moss enveloped with clear flexible plastic film; D -Roots formed in the sphagnum moss ball 45 to 60 days after air layering, ready to be removed from the mother plant.

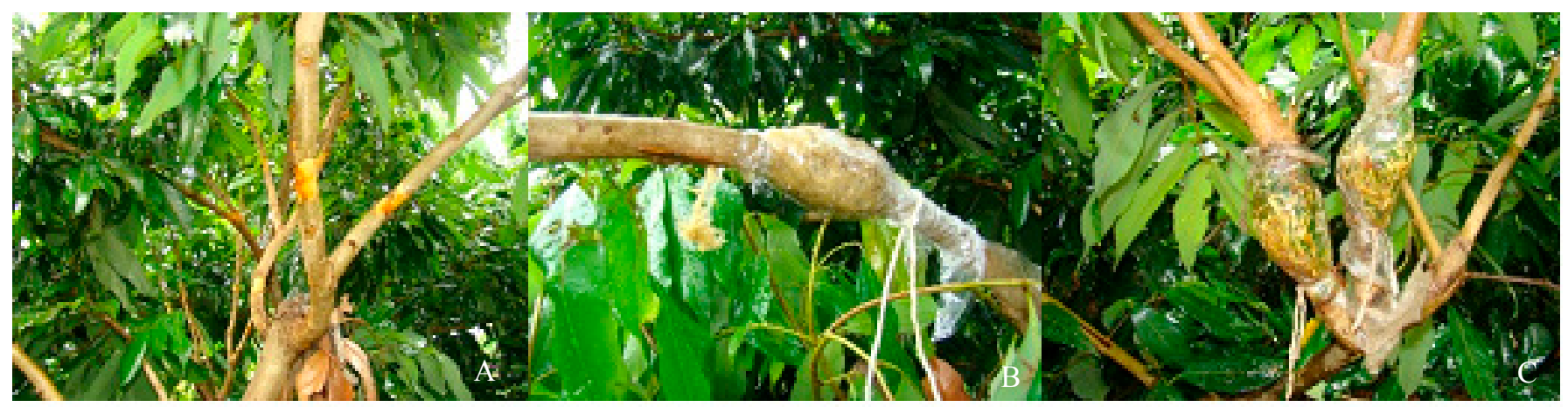

Figure 2. Air layer operation; A- Raw sphagnum moss collected from sea banks; B- Washed sphagnum moss to remove excess of salt kept in the basket with water for hydration; C - Excess of water removed by hand compression prior to enveloping the ring. 


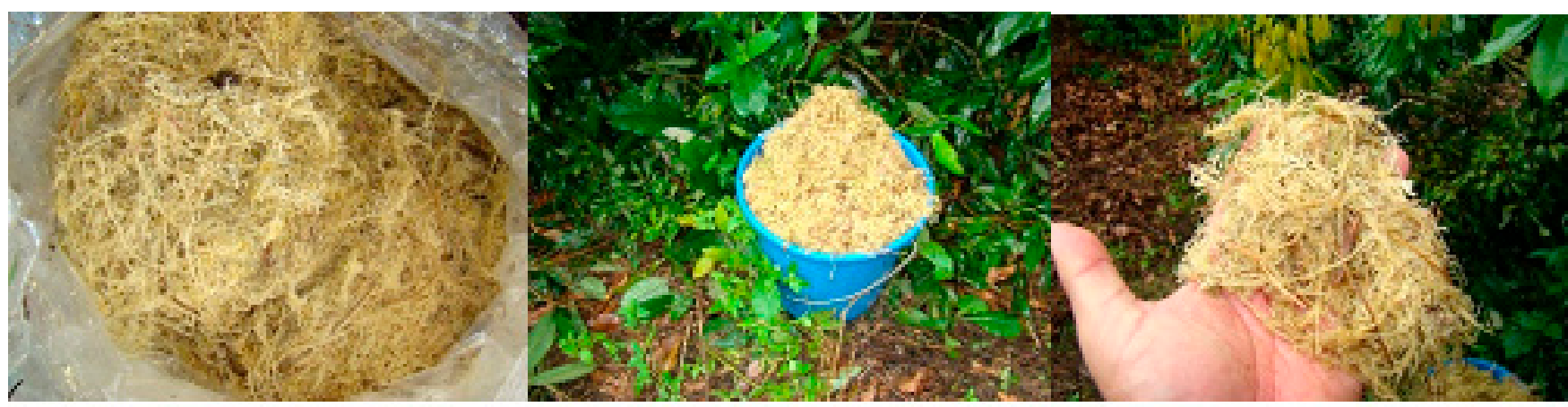

Figure 3. Rooting media for air layering.
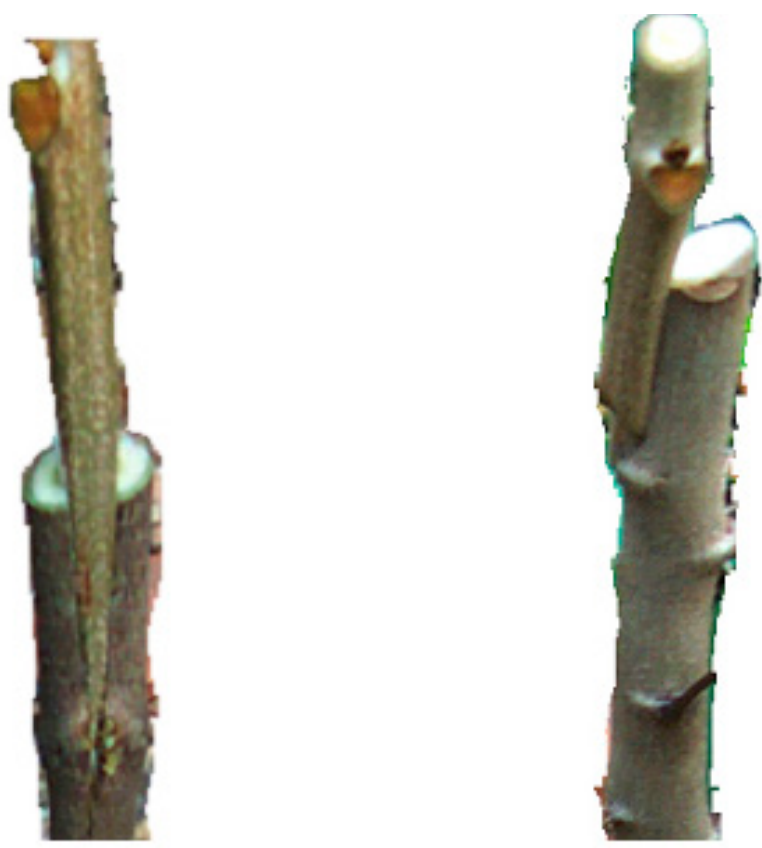

Figure 4. Cleft grafting (left) and bark grafting (right) used for litchi propagation.

\section{Conclusion}

Air layering continues being the commercial practice used in most countries for litchi propagation. Only in China grafting of litchis is also commercially used. Despite grafting can be useful for getting several advantages such early bearing, adaptability to adverse soil environment and facilitate training, more research.

\section{References}

ABUTÍATE, W.S.; NAKASONE, N.Y. Studíes on vegetatíve propagatín of the lyehee (Litehi ehinensis Sonn.) with special references to graftage. Ghana Journal Agricultural Science, Accra, v.5, p.201-211, 1972.

BOLT, L. C. Litchis D-2. Propagation of the litchi. Pretoria: Farming in South Africa. Department of Agriculture, 1983.

CULL, B.W.; PAXTON, B.F.; Growing the lychee in Queensland. Queensland. p.109: 53-60, 1983. 
FU, J.R.; ZHANG, B.Z.; WANG, X.P.; QIAO, Y.Z. AND HUANG, X.L. Physiological studies on desiccation, wet storage and cryopreservation of recalcitrant seeds of three fruit species and their excised embryonic axes. Seed Science and Technology, Zurich, v.18, p.743-754, 1990.

GALÁN SAÚCO, V.; MENINI, U. Litchi cultivation. Rome: FAO Plant Production and Protection, 1989. 136 p. (Paper, 83).

HIGGINS, J.E. The litci in Hawaii. Hawaii: Hawaii Agricultural Experiment Station, 1917. (Bulletin, 44).

HU, G.B.; HUANG, X.M.; BU, J.H. Shoot Growth from Scions Top-Grafted on Different Litchi Cultivars. Acta Horticulturae, The Hague, v.863, p.449-452, 2010.

IRETA-OJEDA, A. Studies on litchi propagation by air layering in Valle de Culiacu. Agriculture Tecnica in Mexico, México, v.3. n.11, p. 418-423, 1975.

KADMAN, A.; SLOR, E. Experiment with propagation of the litchi (Litchi chinensis) in Israel. Indian Journal Horticulture, Dehra Dun, v.31. n.1, p. 28-33, 1974.

KANWAR, J.S.; KAHLON, G.S. Propagation studies in litchi (Litchi chinensis Son.) Journal of Research Punjab Agricultural University, Ludhiana, v.23, n.1, p.33-39, 1986.

LEONEL, S.; RODRIGUES, J.D.; CEREDA, E. Effect of growth regulators and boric acid on lychee cuttings. Cientifica, Jaboticabal, v.22, n.1, p.105-110, 1994.

LI, J.G. The litchi. Beijing: China Agriculture Press, 2008. p.377.

LI, W.C.; WEI, Y.Z.; SHI, S.Y.; WANG, Y.C.; LIU, L.Q.; HU, G.B. Preliminary study on different rootstockscion combinations in 'Shuangjianyuhebao' litchi. Acta Horticulturae, The Hague, v.1029, p.73-80, 2014.

MCCLELLAND, T.B. Brief viability of tropical seeds. Proceedings of the Florida State Horticultural Society, Gainesville, v.57, p.161-163, 1944.
MENZEL, C.M. Propagation of lychee: a review. Scientia Horticulturae, New York, v.25, n.1, p.31-48, 1985

MITRA, S.K.; BOSE. T.K. Metabolic changes during adventitious root formation in Ethrel and IBA treated cuttings of litchi. Indian Journal of Horticulture, New York, v.29, n.1, p.51-53, 1991.

MITRA, S.M.; RAY, P.K. Propagation. In: MENZEL, C. M.; WAITE, G. K. (Ed.). The litchi botany production and uses. Wallingford: Cab International, 2005. p.3548.

MO, W.P.; ZHOU, L.Y.; ZHANG, J.Y.;HUANG, J.B.; BEI, X.W.; FU, X.Y.. WANG, H.C.; HUANG XM. Effects of shading and girdling on shoot growth and photosynthesis in litchi. Acta Horticulturae Sinica, Beijing, v.40, p.117-124, 2013.

NELSON, R.O. Notes on Lychee grafting. Lake Alfred: Florida State Horticultural Society, 1954. p.231-232.

PAXTON, B.; SARANAH, J.; CHAPMAN, K.R. The propagation of lychee by cuttings. Biennial Report Maroochy Horticulture Research Station, Queensland, v.1, p.34, 1978.

PIRES, M.D.; YAMANISHI, O.K.; PEIXOTO, J.R. Top working of 'Bengal' lychee trees in the state o Sao Paulo, Brazil. Revista Brasileira de Fruticultura, Jaboticabal, v.36, n.3, p.680-685, 2014.

RAM, M.; MAJUMDER, P.K. A note on the propagation of litchi. (Litchi chinensis Son.) by stooling. Science and Culture, v.47, p.332-333, 1981.

VENNING, F.D. Anatomy and secondary growth in the axis of Litchi chinensis Sonn). Quartely Journal of the Florida Academy of Science, Orlando, v.12, p.51-60, 1949.

YEE, W. Air layering the lychee. Hawaii: University of Hawaii, Cooperative Extension Service. 1971. (Circular, 60) 